\title{
THE INVESTIGATION OF TAX DISPUTE IN INDONESIA
}

\author{
Inayati Nuraini Dwiputri \\ Jurusan Ekonomi Pembangunan, Fakultas Ekonomi dan Bisnis, \\ Universitas Negeri Malang \\ Inayati.dwiputri.fe@um.ac.id \\ Muhammad Syam Kusufi \\ Jurusan Akuntansi, Fakultas Ekonomi dan Bisnis, \\ Universitas Trunojoyo Madura \\ msyamkusufi@gmail.com
}

\begin{abstract}
The study was aimed to examine the cases of tax dispute in Indonesia. This study will be identified the behavior of verdicts of the Supreme Court, especially indications of tax avoidance by taxpayer and identify the government's loss due to tax avoidance. The data use the verdicts of the Supreme Court regarding to tax disputes in the Supreme Court. Using logistic regression, this study revealed that taxpayer was facilitated to commit tax avoidance by the legal loopholes. The motivation of taxpayers in committing tax avoidance was to utilize the time during the dispute process in accordance to postpone the taxes payment. Delaying tax payment by applying the dispute, taxpayer get benefit from time value of money. From the analysis was, the Indonesian tax laws, somehow, provides opportunities for taxpayers to perform tax avoidance. Moreover, the study showed that the tax laws have not been implemented properly. Accordingly, the loss opportunity cost of the government due to tax avoidance by the taxpayers was approximately 10 billion rupiah. Therefore, based on the result of the study, we advised the government of Indonesia to do some policies, which are: 1) describe the legislation and taxation system with an objective definition; 2) designing administrative processes that can detect the tax avoidance, which is more stringent administrative processes; 3 ) shorten the processing of a tax dispute.
\end{abstract}

Keywords: tax avoidance, tax dispute, tax law, Supreme Court's verdict JEL Classification: H26, K42 


\section{INTRODUCTION}

The highest revenue of Government of Indonesia is come from taxation ${ }^{1}$. Fortunately the taxation revenue was increase in recent years. The government of Indonesia makes minimum target for realization of tax collection. The statistics of Tax Court showed that the amount of filing tax disputes has increased every year. The General Provisions and Tax Procedures Act 6/1983 as amended by Act 16/2000 then revised by Act $28 / 2007$ shows that the completion and the process of tax disputes takes a long time. Nevertheless many people who still continue the tax dispute settlement up to the Supreme Court (SC) level. And, as the laws stipulated that when taxpayers apply the dispute, they can pay the tax only $50 \%$ of tax payment. So, the taxpayer can be facilitated to delay fulfilling tax payment by file tax dispute ( $50 \%$ minimum). If taxpayer utilizes the legal loopholes, it can be categorized to tax avoidance.

The tax laws regulate sanctions and fines for taxpayer who did not meet stipulation. Alm, Bahl, \& Murray (1990) said that improving the severity of sanction and the detection rate could increase tax compliance rate. Regarding to Becker (1968), Casey and Scholz (1991) showed that perpetrators would obtain deterrent effect if there were a high detection but the relatively low sanction rate. Based on literature, tax avoidance can be done by utilizing legal loopholes (Jain, 1987) and defer payment of tax (Stiglitz, 1985). Then, as revealed by Pudyatmoko (2009) that tax laws were made to minimize the chances of taxpayer to abuse opportunity of filing a tax dispute in Indonesia ${ }^{2}$. Abuse of opportunity to filing tax dispute of which is tax avoidance by the taxpayer. Because of tax avoidance could disrupt the smooth acceptance of the state, it is important to analyze the occurrence of tax avoidance in Indonesia. The analysis can be done in cases of tax disputes in the SC level.

Dwiputri (2012) had revealed that there was a hidden action in the tax dispute of Indonesia. Therefore, this study wanted to identify the motivation, and the benefit of taxpayers filed a tax dispute, and how the behavior of verdicts of SC. In addition, the study would identify the indications of tax avoidance by the taxpayer who filed the dispute up to the SC level and it would identify the factors supporting the occurrence of tax avoidance ${ }^{3}$ in Indonesia. Then, to make a rigorous analysis the study would

\footnotetext{
${ }^{1}$ See the more detail in memorandum of Indonesia

${ }^{2}$ Slemrod (1992) found that the reform to tax act, achieved a little simplification in tax system although it can increase the compliance cost.

${ }^{3}$ The study was different with (Desai, 2005 and Desai and Dharmapala, 2006) that measure tax avoidance by using book-tax gap while book-incomes as a proxy for true profits. This study identified tax avoidance as an effort to defer tax payment by filing tax dispute, and the study also identified if the rest of tax payable influence the verdicts of SC in the tax dispute case.
} 
be identified whether the Indonesian tax law still has loopholes that can be used to commit tax avoidance that supporting by empirical data.

Indeed, the successfulness of tax collection do not only measured by achievement of tax revenue target, but also the lower conflicts and disputes. However, the dispute filed by taxpayer had given some problems to Directorate General Taxation (DGT). This study uses data SC's verdict to determine the indication of tax avoidance by the taxpayer. By analyzing the probability of winning the disputing parties in the tax disputes are expected to identify the tax avoidance by taxpayer. In other words, the dispute was favorable taxpayer in general.

From the point of view of some forensic accounting literature, analysis of tax dispute cases through the SC's decision data is included in the verification of cases through documentary evidence. Silverstone and Sheetz (2007) state that proof of a legal case is through inference. That is, the available evidence must go through a process of drawing conclusions (inferential) so as to produce conclusions (proof or conclusion). This research is expected to be the initial research in the field of forensic accounting in taxation disputes in Indonesia that uses inferential statistics to obtain proof, as revealed by Silverstone and Sheetz (2007).

\section{LITERATURE REVIEW}

\section{Tax Avoidance}

Tax avoidance is one of problems in taxation. Tax avoidance is an act of tax deductions by the taxpayer legally (Alm, Bahl, \& Murray, 1990; Cai and Liu, 2009; Gravelle, 2009). Jain (1987) defines tax avoidance as a situation where the taxpayer reduced the tax debt by exploiting legal loopholes and ambiguities or vagueness of law provisions of legislation. In general people do not like imposing tax, because tax can diminish their welfare or arise a loss that acknowledge as excess burden ${ }^{4}$. Understanding the negative impact of tax as welfare loss, make some taxpayers do not comply the tax by committing tax avoidance or tax evasion. Therefore, tax avoidance should be prevented and reduced because it can interfere with even reduce the public budget and lowers national income.

Stiglitz (1985) states that there are three basic principles of tax avoidance on income tax includes the following: (1) postponement of tax; (2) utilization of the law on imposition of different income tax for different income levels, and (3) utilization of the law on imposition of different income tax for different resource of income. Stiglitz (1985) also argues that tax avoidance, sometimes, involves a combination of these. Some research suggests that taxpayers have a tendency to perform tax avoidance on profit-

\footnotetext{
${ }^{4}$ Calculating the loss can use Harberger Triangle (Harberger, 1954, 1959, 1964; Hines Jr., 1999). From demand and supply curve would be shape a triangle, which the area of triangle is loss caused by tax imposion.
} 
oriented enterprises (Cai and Liu, 2009; Dyreng, Hanlon \& Maydew, 2010) or nonprofit corporation (Omer dan Yetman, 2007). Dyreng, Hanlon \& Maydew (2008) found that there were significant fractions of firms that able to avoid large portion of corporate income tax.

Tax avoidance can be identified through two approaches that is cost benefit analysis (Becker, 1968) and game theory analysis (Tsebelis, 1989; 1990; 1993) Becker (1968) assumed that people use cost benefit analysis in committing violation (crime). If expected cost is more that expected benefit so the violation not worth to be done. And vice versa. Tsebelis (1989) argued that the violation (crime) to be done influenced by rational behavior of law enforcer or society. According to Tsebelis (1989; 1990; 1993), the decision to commit violation (crime) does not only depend on the strategy of perpetrators but also influenced by other parties such as law enforcement agencies.

La Brie (1955) argues that tax avoidance occurs because taxpayers reporting tax-free up scandal. Taxpayer commits tax avoidance by utilizing the rules as a justification for not paying taxes (Rice, 1953). And, in fact the taxpayer makes misinterpretation of the laws deliberately (Jain, 1987). So it can concluded that tax avoidance arises because the weakness of the tax laws. Aidt (2003) claims that the problem of taxation depends on the design of government institutions by which were described by three things: the level of wages, monitoring systems and applicable law. However, tax laws constantly changing opportunities for tax avoidance (Stiglitz, 1985). Accordingly, the solution of tax avoidance is changing the tax law (Gravelle, 2009). Therefore, we require an explicit and assertive sentence so that legislation can be immediately understood, implemented and there is no confusion or ambiguity (Angell, 1938; La Brie, 1955). Tax avoidance occurs in the absence of the principle of good management and systems administration in implementing the tax laws that very complicated. It means that the interpretation of judicial to the laws of taxation requires reexamination. Furthermore, Rice (1953) argues that the court should weigh the consequences of tax avoidance.

La Brie (1955) argues that the cause of tax avoidance is due to taxpayers can prepare their tax reporting scandals freely. Indeed tax laws set penalties for taxpayers who do not meet legal requirements. Becker (1968) argues that the perpetrators will get a deterrent effect when the detection rate is high relatively with the low sanctions. Becker's (1968) opinion is supported by Casey dan Scholz (1991) that, if the probability of detection and punishment in high levels, therefore the taxpayer's compliance to the tax law will increase.

Jain (1987) said that some ways to reduce tax avoidance are: 1) eliminate the loopholes in tax law; 2) designing administrative processes that can detect the presence of tax avoidance; 3) improve standards of administration; 4) invites the public and social institutions to combat tax 
avoidance. Steenkamp (2012) suggested that the use of administrative techniques that include awareness resources, monitoring tools, audits and administrative penalties can minimize the occurrence of tax avoidance.

Some studies reveal that the majority of the taxpayers have a tendency to make tax avoidance both profit-oriented enterprises (Cai dan Liu, 2009; Dyreng, Hanlon, \& Maydew, 2010) and non-profit company (Omer dan Yetman, 2007). Tax avoidance is a lot happening at the company in a more competitive environment, and higher levels of tax avoidance going on the company that relatively unprofitable or loss (Cai dan Liu, 2009). Dyreng, Hanlon, \& Maydew (2010) reveals that the executive plays a significant role in determining the level of tax avoidance by the company. Schwarz (2009) shows that American multinational company allocated the profit to commit tax avoidance (Schwarz, 2009).

\section{Tax Dispute Settlement}

This study examined the tax dispute in the case of appeals against the amount of tax payable. According to Tax Court Act 14/2002, lawsuit does not delay or impede the implementation of tax collection or tax liabilities. Nevertheless the plaintiff can apply for delaying tax collection during the examination of tax disputes, until there is a Tax Court's verdict. Application for postponement can be granted only if there is urgency that resulting the plaintiff's interests was harmed if the tax collection implemented. In the case of appeal, appeal can be filed only if the tax payable is paid minimum at $50 \%$.

Related to the definition of tax avoidance, it inferred that taxpayer who file tax dispute can be benefited by the laws to commit tax avoidance by reducing the present value of money. According to Tax Court Act $14 / 2002$, application for review can only be filed once to SC through the Tax Court. Application for review does not suspend or stop the implementation of the Tax Court's verdict. The reason of application for review can be submitted to the SC are as follows: 1) if the Tax Court's verdict based on a lie or tricks from the opponent that are known after his case terminated, or, based on evidence that declared as bogus evidence by the judge; 2 ) if there is new evidence that important and decisive, that, if known at the stage of proceedings in the Tax Court will produce a different verdict; 3 ) if has been granted a thing that is not required or more than the required, except for verdict 'granted in part or granted all' and 'add amount of the tax'; 4) if the application of review about a part of the claim that has not been terminated without consideration its causes; 5 ) if there is a verdict which obviously does not correspond to provisions of laws.

\section{Hypothesis Development}

The study carried out in cases of disputed value added tax because it provides the second largest proportion of domestic tax revenue after 
income tax ${ }^{5}$. From the survey known that the amount of dispute of value added tax is more than income tax. The study wanted to identify the behavior of the verdicts of SC. It would be identify if there were no tendencies of the verdicts of SC to the characteristics of taxpayers. The characteristics of taxpayer consist of the ownership of contract of work, the category of foreign investment company, category of mining enterprise, residential location of taxpayer, and categorization to state-owned enterprise.

The study wanted to know whether the ownership of the contract of work by taxpayer influence the verdicts of SC. Contract of work is an agreement between taxpayer and Government of Indonesia on the tax policy for taxpayer (company). Thus, the taxpayer who has a contract of work will get different treatment in taxation. In addition, the study wanted to know whether location of taxpayer could influence the verdicts of SC. Indonesia as the archipelago country that still has inequality in development make the different quality of institutional system in some area especially between area around the capital city, i.e. Jakarta, Bogor, Depok, Tangerang and Bekasi (known as Jabodetabek) and not around the capital city.

The last, this study wanted to identify tendency of the verdicts of SC to dispute duration. However, the dispute can take a long or short time depends on the case of dispute. During the dispute, DGT examined the proofs provided by taxpayer. So, duration dispute is an important part in the conflict ${ }^{6}$. It was because there were larger costs would be imposed for a longer duration of dispute. The costs that imposed by DGT were opportunity cost of tax payment, and if taxpayer wins the dispute, DGT must be pay the disbursement to taxpayer in the amount of $2 \%$ per month of excess the payment of tax maximum for 24 months. On the contrary taxpayer would get some benefits from dispute let alone if taxpayer wins the dispute. But, taxpayer should provide some proofs to support their own tax calculation and disposed to be examined by DGT. It was time consume. But, it would be a less cost if taxpayer can win the dispute; they only paid tax as their calculation and got some interest of the excess tax paid from the DGT. Furthermore, the study would identify the existence of tax avoidance in the tax dispute.

It wanted to identify tendency of the verdicts of SC to amount of tax that have not paid yet by taxpayer because of it still in dispute. As stated above that when applying dispute, taxpayer only paid $50 \%$ of tax payment according to the law. Then taxpayer can use the remains of it (50\% of tax payment) for other purposes including investment, capital or utilize it as

\footnotetext{
${ }^{5}$ Financial Memorandum 2014 showed that income tax had contributed as 52,62\%, while value added tax had contributed as $33.68 \%$ of domestic tax revenue.

${ }^{6}$ In militarized context, Bennett (1998), Krustev (2006) also said that duration dispute is an important part of the conflict process. Longer conflicts lead to greater potential costs for all parties (Koch, 2009). Although in the tax dispute, duration time is also important.
} 
management of cash flow. This study identified the motivation of the taxpayer filed a tax dispute. It inferred that taxpayer had benefited by the law that can be categorized to tax avoidance according to the definition. So the study wanted to identify if the remain of tax payment can influence the verdicts of SC and how the interaction of remain tax payment and the dispute duration can influence the verdicts of SC. It noted that longer duration dispute more benefit taxpayer can get from time value of money (remain of tax payment).

In the tax disputes, there are two probabilities of verdicts of SC, these are winning The Director General of Taxation or not winning The Director General of Taxation. In other words, the verdicts benefitted taxpayer or not. If it is assumed that the taxpayers have a high loyalty to pay taxes, then the taxpayer will pay the entire tax payable although it is still in dispute. If it is assumed that the taxpayers have less loyalty in paying taxes, then the taxpayers will take the advantage of tax dispute to make tax avoidance, i.e. defer tax payments (Stiglitz, 1985). Allegedly the purpose of taxpayer filed a dispute was to make tax avoidance and the taxpayers know if they will not win a tax dispute. It inferred that benefit of taxpayer in filing the dispute would motivate taxpayer to commit tax avoidance. So, if the benefit variable that proxy as the amount of remains of tax payable (50\% of tax payment) has positive significant effect to the verdicts of SC in benefitted The Director General of Taxation ${ }^{7}$ indicate the presence of tax avoidance by taxpayer. In this case benefit variable means that time value of money for postponement of tax as minimal benefit that the taxpayer get in the filing tax dispute.

\section{RESEARCH METHODOLOGY}

\section{The Data}

The data used the verdicts of SC to the review on the verdict of Tax Court in tax disputes cases. The data was taken from the SC's verdict in 2004 because of recent legislation; The Tax Court Act 14/2002 has been implemented. The verdicts of SC from year 2004 have referred to that law. The study was limited only to taxpayers who submit the dispute to the SC level because of the availability of data. Data obtained from the SC's website: http://putusan.mahkamahagung.go.id.

\section{Model Specification}

This study uses logistic regression analysis with the following equation: $\operatorname{Ln}\left(\frac{P i}{1-P i}\right)=Z_{i}=\beta_{0}+\beta_{i} X_{i}$. The research model is as follows:

\footnotetext{
7 It means that not benefitted taxpayer
} 


$$
\begin{aligned}
& Y_{i}=L_{i}=\operatorname{Ln}\left(\frac{P_{i(1)}}{1-P_{i(1)}}\right)=Z_{i(1)}=\beta_{0}+\beta_{1} D_{-} \text {Residence }_{i}+\beta_{2} D_{-} \text {Mining }_{i}+\beta_{3} \\
& \text { D_pma }+\beta_{4} D_{-} \text {bumn }_{i}+\beta_{5} D_{-} K_{K}+\beta_{6} \text { Mining*pma }+\beta_{7} \\
& \text { Ln_gap }_{i}+\beta_{8} \text { Ln_duration }_{i}+\beta_{9} \text { gap*duration }+\beta_{10} \text { Ln_benefit }+ \\
& \text { whereas: } \\
& \beta_{11} \text { benefit*duration }+e_{i}
\end{aligned}
$$

D_Residence : residence of taxpayer (dummy variable; 1 if taxpayer live in area around the capital city (i.e. Jakarta, Bogor, Depok, Tangerang and Bekasi/Jabodetabek) and 0 if live in not around the capital city)

D_Mining : categorization taxpayer to mining company (dummy variable; 1 if taxpayer categorized to mining company and 0 if not)

D_pma : dummy categorization taxpayer to foreign investment company/PMA ( 1 if taxpayer categorized to PMA company and 0 if not)

D_bumn : categorization taxpayer to state-owned enterprise / BUMN (dummy variable; 1 if taxpayer categorized to BUMN company and 0 if not)

D_KK : ownership of contract of work by taxpayer (dummy variable; 1 if taxpayer has contract of work and 0 if not)

Ln_gap : gap of tax payable calculation (rupiah) in Ln

Ln_duration : dispute duration (days) in Ln; time for processing the application of review

Ln_benefit : benefit variable; $50 \%$ of remains the tax payment that has not been paid yet by taxpayer due to the dispute that proxy benefit from time value of money by filing the tax dispute

$\mathrm{e}_{\mathrm{i}}$ : error term

Ln_Benefit variable in this study represented the existence of tax avoidance. The study aimed to determine the behavior of verdicts of SC, if there were tendencies of verdicts to the characteristics of taxpayer, tax payable calculation gap, and dispute duration. Also, the study aimed to determine the indication of tax avoidance in the case of tax disputes. To analyze the existence of tax avoidance, we tested the significances of benefit variable to the verdicts of SC in favorable taxpayer. If benefit variable has negative significant effect to verdicts of SC makes the probability of The DGT to winning tax dispute to be higher. It indicated the presence of taxpayer's benefit. This applied to taxpayers who committed tax avoidance. It is assumed that motivation of taxpayer commit tax avoidance is to defer tax payments by submitting the dispute. For the 
rigorous analysis, this indication will be identified descriptively through the behavior of taxpayers in filing a dispute and an analysis to the tax laws.

\section{RESULT AND DISCUSSIONS}

\section{Descriptive Analysis}

The data shows the verdicts of SC for review verdicts of Tax Court consist of 328 verdicts; 283 verdicts with application review qualified the requirements and 45 verdicts did not meet the requirements for review application. So that 45 verdicts decided to win DGT. There were two types of disputes, objection and appeal. Objection dispute questioned about the implementation of law such as decision of DGT. Appeal dispute questioned the difference calculation of tax payable between taxpayer and DGT. The study would be analyzed tax dispute in accordance to difference tax payable calculation between taxpayer and DGT (appeal case) because it was the basic problem related to monetary benefit from dispute as question of study. Then of 283 verdicts, there were 232 verdicts that have information about variables to be studied and categorized to appeal case. So, the analysis will be done to 232 verdicts, which met the requirement to dispute and have information about variables to be studied. There were 96 or $41.38 \%$ disputes were applied by the taxpayer and 136 cases or $58.62 \%$ were applied by the Directorate General Taxation. From those 232 verdicts, there were 147 review applications or $63.36 \%$ were favorable to taxpayer and 85 review applications or $36.64 \%$ were not.

The period of processing the review application (duration dispute) is an important thing into consideration for taxpayers in filing tax dispute. From the data, dispute duration in processing the review of verdict of Tax Court takes a minimum of 84 days or approximately 3 months and maximum time is 2411 days, more than 80 months or less than 7 years. Averagely, it needs approximately 830 days or 27 months to finish all the review process since the filing tax dispute to Tax court for review of verdict of Tax Court by SC. It means that duration dispute take a long time period.

As explained previously that taxpayer who filed a dispute can pay $50 \%$ of tax payable. And remains from it (50\%), can pay after the dispute finished; there was verdict from court. Taxpayer who has high level of tax compliance and ability to pay will pay all of tax payable. From the data, it known that the lowest remains of tax payable by taxpayer before filing the dispute was about 0 rupiah, it means that taxpayer pay all of tax payable before filing dispute. And, the highest was about 38.6 billion rupiahs. It showed that there was much benefit of taxpayer in deferring tax payment by filing the dispute. When the dispute duration, taxpayer can utilize that fund for investment and others. Minimum benefit that taxpayer can get was lessen the time value of money of remains the tax payment due to the differing remains payment because of dispute duration. 
Tax dispute in the SC level is questioned about the calculation gap of tax payable. The differences of tax payable calculations indicate that there was hidden information by either party between the taxpayer and/or tax authorities. The lowest gap calculation discovered from the data was about 9 million rupiahs and the highest was about 77.2 billion rupiahs. On the average, the gap calculation was about 3 billion rupiahs. Further, it would be compare the gap tax calculation between taxpayers who have a contract of work and which do not. It is known that the average of the gap calculation of the amount of taxes payable for taxpayers who have a contract of work is higher than taxpayers who do not have a contract of work. On the average, the tax calculation gap between taxpayers who have a contract of work was higher than taxpayers who do not have contract of work. On the average, tax calculation gap for taxpayer who has contract of work was about 4.46 billion rupiahs, and calculation gap in case taxpayer who has no contract of work was about 2.53 billion rupiahs.

Based on Tax Court Act 14/2002, appeal may be filed if the amount of tax payable has been paid by $50 \%$. Thus, if the taxpayer complied with the provisions of that law (pays $50 \%$ of tax payable), then the taxpayer can take advantage from the processing time of a tax dispute in the Tax Court to defer tax payments by $50 \%$, the rest of the tax payable. From the data known that the time between issuance of Tax Underpayment Assessment Letter [Surat Ketetapan Pajak Kurang Bayar (SKPKB)] until the Tax Court's verdict on the average was 27 months. Thus, the taxpayer can take approximately 27 months or 2 years and 3 months to defer payment of $50 \%$ of tax payable. Postponement of tax payment by the taxpayer is one category of tax avoidance measures (Stiglitz, 1985). So this policy has a legal loophole that can be utilized by the taxpayer to make tax avoidance by filing a tax dispute.

If the tax disputes still proceed to SC level, so the taxpayer also take advantage the processing time of review application (dispute duration). Based on the Tax Court Act 14/2002, a review application does not suspend or stop the implementation of the Tax Court's verdict. However, from the data was known that there are some taxpayers who still have not paid taxes payable in applying review for the Tax Court's verdict. This indicates that the tax law has not been implemented properly. Thus, dispute duration up to SC level can utilize taxpayer to commit tax avoidance. We recommend the implementation of these laws is the fulfillment of the Tax Court's verdict, the repayment of taxes payable as a requirement for taxpayers to apply for a review. That implementation is expected to reduce and even eliminate the taxpayer opportunity to commit tax avoidance.

From the data there were 85 verdicts which do not fulfilled the requirements for review application, but only 62 verdicts which has the qualified information about the kind of requirement which not fulfilled. They are: 1 ) exceed the specified time limit as 22 cases; 2) not pay $50 \%$ of tax 
payable when apply for appeal as 26 cases; 3) and others as 14 cases. All review application that past the time limit conducted by the taxpayer. However, the reasons of review application beyond the specified time could not be identified by the SC's verdict beam as described in Table 4.1.

Table 1. The Requirement Deviation By The Taxpayer

\begin{tabular}{|c|r|c|}
\hline $\begin{array}{c}\text { Type of Deviation The } \\
\text { Requirement }\end{array}$ & $\begin{array}{c}\text { Amount } \\
\text { case) }\end{array}$ & $\begin{array}{c}\text { Percentage } \\
(\mathbf{\%})\end{array}$ \\
\hline ceed the specified time limit & 22 & 35,48 \\
\hline ot pay 50\% of tax payable & 26 & 41,94 \\
\hline Others & 14 & 22,58 \\
\hline Total & 62 & 100 \\
\hline
\end{tabular}

Source: Supreme Court's Verdict, processed

Appeals that do not meet the requirements that do not pay $50 \%$ of tax payable will be rejected by the Tax Court, because the appeal that do not meet these requirements can not be considered further. Yet taxpayers still apply for review application to the Supreme Court against the Tax Court's verdict. Thus, filing a tax dispute to the SC level can be a means for taxpayers to make tax avoidance. From the data known that the highest proportion of the requirement deviation was the taxpayer did not pay $50 \%$ of tax payable when applied the appeal.

Motivation taxpayer filed a tax dispute is like to win a tax dispute. However, some other taxpayer filed a tax dispute indicating is like to make tax avoidance. It is proved that there are some taxpayers who deliberately do not meet the filing requirements of tax disputes. Upon the application of appeal that does not fulfill the requirements, the Tax Court decided not to accept the appeal because it could not be considered further. However, taxpayers are still continuing their disputes to the SC level although they were not fulfilling the requirements. So, there are indications that the taxpayer has to know if it will not win a tax dispute because it does not fulfill the filing requirements of disputes, but the taxpayers are still continuing the dispute to the SC level. This indicates tax avoidance by the taxpayer. The deeply analysis is test the significance of benefit variable in the model.

Through the data can be identified that taxpayers do not pay $50 \%$ of the taxes payable because of intentional, this indicates that the Tax Court Act is not implemented properly. The taxpayers have taken advantage of the processing time for appeals and review application even violate the Tax Court Act 14/2002. Tax Court Act 14/2002 stipulates that before an appeal, the taxpayer must pay $50 \%$ of tax payable. However, in the Tax Court Act and the KUP Act, has not been set of sanctions if it does not meet these provisions. The existence of taxpayers who not pay $50 \%$ of the taxes payable prior to submitting an appeal indicate deviation by the taxpayer. However, for this deviation has not been set up the legal sanctions. 
If identified, the benefits obtained by taxpayers who do not meet the filing requirements of the dispute are enough large. Taxpayers do not get penalized for the violation. In addition, if the taxpayer does not pay $50 \%$ of tax payable, taxpayers can use to manage cash flow or obtain the benefit of time value of money (TVM), where the benefit of TVM is higher than $2 \%$ (exchange rate by the DGT if there is an overpayment). In this case it is assumed minimal benefit taxpayers on time value of money at deposit interest per month on the amount that should be paid. Average deposit rate recently was $9.30 \%$. Therefore, taxpayer who behave rationally then choose not to comply with these regulations, moreover the time processing review application that can be utilized on average is approximately 601 days or 20 months.

Thus, it can be concluded that the taxpayer may make tax avoidance by utilizing filing a tax dispute in two ways: 1 ) eligible to pay $50 \%$ of tax payable; 2 ) not eligible to pay $50 \%$ of tax payable because there is no sanction for this violation. However, a taxpayer who has met the requirements to pay $50 \%$ of the taxes payable, it does not mean has made tax avoidance. However, taxpayers were given the facility to make tax avoidance. So, it needs to be consideration for the government to regulate the policy of the filing requirements of tax disputes. The logistic regression of the 232 Supreme Court's verdicts showed that in the table 2 below.

Residence of taxpayer has no significant effect on verdicts of SC. The residence of taxpayer in Jabodetabek or outside Jabodetabek does not affect the verdicts of SC, although the position of the Supreme Court in Jakarta. It means that there was no tendency of verdicts of SC to taxpayers who live in Jabodetabek or outside Jabodetabek. The categorization of taxpayer to BUMN Company also does not have significant effect to verdicts of SC. It means that there was no tendency of verdicts of SC to taxpayers who categorized to BUMN Company or not. Also, the categorization of taxpayer to mining company does not have significant effect to verdicts of $\mathrm{SC}$. It means that there was no tendency of verdicts of SC to taxpayers who categorized to mining company or not. The categorization of taxpayer to PMA Company has positive significant effect to verdicts of SC. The probability of verdict favorable taxpayer that categorized to PMA Company was higher than taxpayer who does not. But, interaction variable between categorization of PMA and mining company does not influence the verdicts of SC.

\section{Table 2. Indication of Tax Avoidance}

Dependent Variable: the verdict of Supreme Court ( 1 if the verdict is favorable to tax payer; and 0 if the verdict is not favorable to tax payer)

Independent Variable Characteristic of taxpayer: Mining enterprise (Yes=1) PMA enterprise $(Y e s=1)$

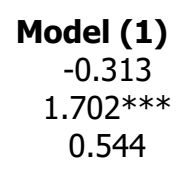

Model (2)

$-0.784$

$1.822 * * *$
Model (3)

$-1.480$

$2.133 * * *$ 


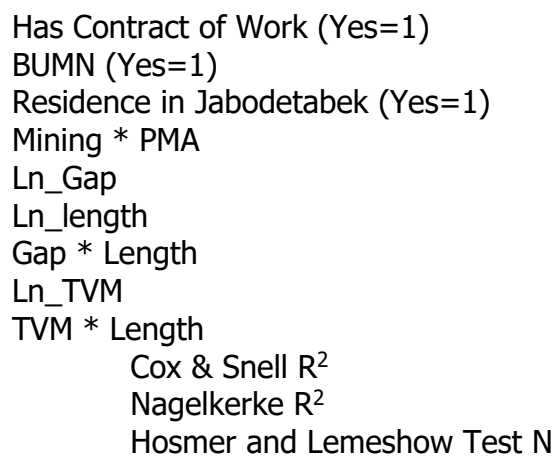

$\begin{array}{ccc}1.072 & 0.352 & 0.648 \\ -0.131 & -0.086 & 0.152 \\ -1.524 * & -0.364 & -0.125 \\ & -1.279 & -0.506 \\ & -2.113^{* *} & -2.180^{*} \\ & -7.838^{* *} & -7.254^{* *} \\ & 0.384^{* *} & 0.373^{* *} \\ & & 0.433^{* *} \\ 0.070 & & -0.055^{* *} \\ 0.095 & 0.164 & 0.232 \\ 6.762 & 0.225 & 0.317 \\ 232 & 4.217 & 5.700 \\ & 232 & 232\end{array}$

Note : ***: significant at $\mathrm{a}=0,01 ; * *$ : significant at $\mathrm{a}=0,05 ; *$ : significant at $\mathrm{a}=0,1$

Source: Verdicts of SC, to be estimated

Ownership of contract of work by taxpayer does not have significant influence to the verdicts of SC, although taxpayers who have contract of work get some ease in taxation from government. The verdicts of SC does not have tendency to taxpayers who have contract of work as well as taxpayers who do not have contract of work with the government.

As stated previously that dispute duration is an important part of dispute. If there was a problem of moral hazard in tax dispute, the dispute duration can utilize to do some hidden action (moral hazard) ${ }^{8}$ in an effort takes the benefit of dispute. The examination showed that dispute duration has negative significant effect to the verdicts of SC. Thus, the shorter time required processing the review application (dispute duration), the higher probability of verdicts of SC favorable to taxpayer. Conversely, the longer it takes to process the review application, the lower probability of verdicts of SC to be favorable taxpayer. Thus, the verdicts of SC have a tendency to dispute duration variable. This shows an indication that tax laws were not implemented properly because the verdicts of SC depend on the time processing of review application (dispute duration).

Section 93 subsection 1 letter a in the Tax Court Act 14/2002 stated that:

"The Supreme Court examine and decide an application for review with the provisions of: within a period of 6 (six) months from the application for review is received by the Supreme Court has taken a decision, in terms of the Tax Court reached a decision through regular inspection program".

According to Section 81 in the Tax Court Act 14/2002 stated that examination of the event common decision on the appeal is taken within 12 (twelve) months from the letter of appeal received. Furthermore, in specific things, such period may be extended no longer than 3 (three) months. So if there are specific things, the total period of examination of the appeal is

\footnotetext{
${ }^{8}$ Hidden action (moral hazard) arises when a party cannot observe the action of another party (Baiman, 1982; Eisenhaur, 2006).
} 
15 months. However, according to data, the time review application process on average is 830 days or approximately 27 months. This is proved if the Tax Court Act 14/2002 was not implemented properly in particular Section 81.

Related to tax calculation gap, as a basic problem of dispute, from analysis is known that tax calculation gap has significant negative effect to verdicts of SC. It means that the higher tax calculations gap the lower probability of verdict favorable taxpayer. And on the contrary, the lower tax calculations gap the higher probability of verdict favorable taxpayer. Furthermore interaction between tax calculation gap variable and duration variable has a positive significant effect to verdicts of SC. It means that the higher and the longer dispute duration, the higher probability of verdicts of SC favorable taxpayer.

From the law known that it inferred that tax avoidance was performed by taxpayer who filing a tax dispute, allegedly because it has provided benefits in the form of time value of money from the tax payable. It would be identified in influencing of benefit variable to verdicts of SC. The analysis showed that verdicts of SC have tendency to the benefit variable. The benefit variable has positive significant effect to verdicts of SC. The higher benefit for time value of money (TVM) acquired by a taxpayer upon filing of tax disputes, then the higher probability of verdicts of SC favorable taxpayer compared to the lower benefit over TVM acquired by a taxpayer upon filing of tax disputes. Furthermore, the interaction of benefit variable and dispute duration variable showed negative significant effect to verdicts of SC. It means that the higher benefit of TVM and the longer dispute duration, then the higher probability of verdicts of SC favorable taxpayer. This is an indication that taxpayers take advantage of a tax dispute to get the benefit of time value of money. Thus there is an indication of tax avoidance by the taxpayer.

If it is assumed that the taxpayer who have high loyalty to pay taxes then the taxpayer will pay the entire tax payable although it is still in dispute. Furthermore, it is assumed that the taxpayer who have less high loyalty in paying taxes, then taxpayer will take advantage of a tax dispute for tax avoidance (in this case delaying tax payments). Thus, in this case taxpayer filed a tax dispute on purpose only to make tax avoidance and taxpayers know if they will not win a tax dispute. If so, then the benefit of TVM acquired by a taxpayer upon filing of tax disputes will significantly affect to verdicts of SC. This is because any benefit over TVM which the taxpayer acquired, encourage taxpayer filed a tax dispute though it has been suspected or knew in advance if it is not going to win a tax dispute. Thus, benefit of TVM encourages taxpayers to make tax avoidance.

The implications of the implementation of these rules are not properly facilitated taxpayers to make tax avoidance. According to data, in practice, the time used to processed review application (dispute duration) 
had exceeded the time that allowed by tax laws. Because of a relatively long time, providing benefits for TVM for taxpayers. Thus, the judicial system also contributed in facilitating the taxpayers to make tax avoidance.

These results indicate that WP that categorized to PMA entreprise tends to carry out accounting conservatism, which is delaying the recognition of income and accelerating the recognition of costs so as to reduce the amount of taxable income (or the basis of taxation) and finally can delay the payment of taxes (Dwimulyani, 2010). This finding indicates that higher accounting conservatism also occurs in companies that are categorized as PMA entreprise causing a tax dispute compared to companies that are not categorized as PMA entreprise. Nevertheless, further research is needed related to these findings.

\section{Government Losses Due to Tax Avoidance}

A clear indication of tax avoidance is the filing of a tax dispute that not eligible. Of the data SC's verdict known that there are 62 applications that do not meet the filing requirements of disputes. As described previously, there were indications that taxpayers who do not meet the filing requirements of disputes take advantage of filing a tax dispute to get the benefit of TVM.

It is assumed that the taxpayer depositing the money in the bank on a monthly worth of unpaid tax debts. Interest on deposits is an acceptable minimum benefit for taxpayers due to delayed payment of taxes through the filing of a tax dispute. The taxpayer's benefit is a lost opportunity cost for the government. Thus the government's losses due to tax avoidance worth of taxpayer benefits on time value of money that is more than 15 billion dollars ${ }^{9}$. The loss is not taking into account the loss of tax avoidance that takes advantage of dispute, which only came to the Tax Court.

At 62 review application that not eligible to filing tax dispute takes on average for approximately 240 days or 8 months for processing the dispute. Based on the data is known that the minimum time required is 115 days or approximately 4 months and the maximum time required is 1481 days or approximately 4 years. This time is quite beneficial to taxpayers because any benefit over time value of money. So, process the application that is not eligible should be further shortened.

\section{CONCLUSIONS AND POLICY IMPLICATIONS}

The research's results showed that there are still a lot of taxpayers who do not meet the provisions of tax law in filing a tax dispute. Taxpayers who filed a tax dispute without fulfilling the provisions of tax law is an indication of tax avoidance. This is because, when viewed from the system

\footnotetext{
${ }^{9}$ It calculated from the data of this study
} 
of taxation legislation in Indonesia, can be identified that there are legal loopholes that can be utilized for tax avoidance. In addition, there is the benefit of TVM that earned by the taxpayer who filed a tax dispute. Even, the judicial system also facilitates the taxpayer to makes tax avoidance by processing of tax disputes in a long time beyond the time stipulated in tax laws. Thus, the review application that do not meet the filing requirements of tax disputes should be processed in a shorter time so that the government's losses can be reduced or even abolished.

From the data noted that there were some taxpayers who do not meet the Tax Court's verdict. Thus, the filing of review application can be a means to make tax avoidance. So, should be considered that the filing requirement is also included evidence of the taxpayer meets the Tax Court's verdict. Thus, the government has not harmed any filing of review application. It was known that an important issue in the case of a tax dispute is the time of dispute process. Under the tax laws, dispute process is time since the issuance of tax assessments up to the Supreme Court's verdict is a maximum of 2 years. However, based on the data, the implementation takes approximately 4 years.

If the time of tax dispute process can be minimized, then the tax avoidance can be avoided or even abolished. This is because the benefit of the taxpayer of the dispute to be very small or even absent. In addition, if the dispute process in minimum time, taxpayers will not feel too aggrieved if the filing of the dispute required payment terms $100 \%$ of tax payable. This is because if there is excess payment then the taxpayers will soon acquire the excess tax payments. Hopefully this policy will form the taxpayer who has more loyalty in paying tax payable.

From the identification of research results and refers to previous research, it needs to be done by the government of Indonesia, among others, are: 1) make changes in tax legislation system with an objective definition and does not cause confusion; 2) designing administrative processes that can detect tax avoidance, which is more stringent administrative processes; 3 ) invites the public and social institutions to combat tax avoidance; 4) shorten the processing time of a tax dispute.

\section{REFERENCES}

Act Number 14 Year 2002 concerning the Tax Court

Act Number 16 Year 2000 concerning the Second Revision on Act Number 6 Year 1983 concerning General Provisions and Tax Procedures.

Act Number 28 Year 2007 concerning the Third Revision on Act Number 6 Year 1983 concerning General Provisions and Tax Procedures.

Act Number 6 Year 1983 concerning General Provisions and Tax Procedures. 
Aidt, Toke S. (2003). Review: Economic Analysis of Corruption: A Survey, The Economic Journal. 113(491): F632-F652.

Alm, James, Bahl, Roy and Murray, Matthew N. (1990). Tax Structure and Tax Compliance, The Review of Economics and Statistics. 72(4): 603613.

Angell, Montgomery B. (1938). Tax Evasion and Tax Avoidance, Columbia Law Review. 38(1): 80-97.

Baiman, S. (1982). Agency Research In Managerial Accounting: a survey, Journal of Accounting Literature. 1: 154-213.

Becker, G.S. (1968). Crime and Punishment: an Economic Approach, Journal of Political Economy. 70:1-13.

Benneth, D. Scott. (1998). Integrating and Testing Models of Rivalry Duration, American Journal of Political Science. 42(4): 1200-1232.

Cai, Hongbin and Liu, Qiao. (2009). Competition and Corporate Tax Avoidance: Evidence From Chinese Industrial Firm. The Economic Journal. 119(April): 764-795.

Casey, Jeff T. and Scholz, John T. (1991). Beyond Deterrence: Behavioral Decision Theory and Tax Compliance. Law and Society Review. 25(4): 821-844.

Desai, M. (2005). The Degradation of Reported Corporate Profits. Journal of Economic Perspectives. 19(1): 171-192.

Desai, M and Dharmapala, D. (2006). Corporate Tax Avoidance and High Powered Incentives. Journal of Financial Economics. 79(1): 145-179.

Dwimulyani, Susi, 2010. Konservatisma Akuntansi dan Sengketa Pajak Penghasilan: Suatu Investigasi Empiris. Paper dipresentasikan di Simposium Nasional Akuntansi XIII, Universitas Jenderal Soedirman, Purwokerto.

Dwiputri, I.N. (2012). "Hidden Action in the Case of Tax Disputes in Indonesia". Journal of Indonesian Economy and Business 27(3): 373389.

Dyreng, Scott D., Hanlon, Michelle and Maydew, Edward L. (2008). LongRun Corporate Tax Avoidance. The Accounting Review. 83(1): 61-82.

Dyreng, Scott D., Hanlon, Michelle and Maydew, Edward L. (2010). The Effects of Executives on Corporate Tax Avoidance. The Accounting Review. 85(4): 1163-1189.

Eisenhauer, Joseph G. (2006). Severity of Illness and the Welfare Effects of Moral Hazard. International Journal of Health Care Finance and Economics. 6(4): 290-299.

Gravelle, Jane G. (2009). Tax Havens: International Tax Avoidance and Evasion. National Tax Journal. LXII(4): 727-753.

Harberger, Arnold C. 1964. The Measurement of Waste. American Economic Review. 54(3): 58-76.

Harberger, Arnold C. (1954). Monopoly and Resource Allocation. American Economic Review. 44(2): 77-87. 
Harberger, Arnold C. (1959). Using the Resources at Hand More Effectively. American Economic Review. 49(2): 134-146.

Hines Jr., James R. (1999). Three Sides of Harberger Triangles. Journal of Economic Perspectives. 13(2): 167-188

Jain, Anil Kumar. (1987). Tax Avoidance and Tax Evasion: The Indian Case. Modern Asian Studies. 21(2): 233-255.

Koch, Michael T. (2009). Governments, Partisanship, and Foreign Policy: The Case of Dispute Duration. Journal of Peace Research. 46(6): 799817.

Krustev, Valentin L. (2006). Interdependence and the Duration of Militarized Conflicts. Journal of Peace Research. 43(3): 243-260.

La Brie, F.E. (1955). The Role of the Courts in Tax Avoidance. The University of Toronto Law Journal. 11(1): 128-138.

Omer, Thomas C and Yetman, Robert J. (2007). Tax Misreporting and Avoidance by Nonprofit Organizations. JATA. 29(1): 61-86.

Pudyatmoko, Y.Sri, (2009). Court and Dispute Resolution in the Field of Taxation [Pengadilan dan Penyelesaian Sengketa di Bidang Pajak]. Revision edition. Jakarta: PT Gramedia Pustaka Utama.

Rice, Ralph S. (1953). Judicial Techniques in Combating Tax Avoidance. Michigan Law Review. 51(7): 1021-1052.

Schwarz, Peter. (2009). Tax-Avoidance Strategies of American Multinationals: An Empirical Analysis. Managerial and Decision Economics. 30: 539-549.

Silverstone, Howard, and Sheetz, Michael., 2007. Forensic Accounting and Fraud Investigation for Non-Experts. $2^{\text {nd }}$ Edition. John Wiley \& Sons, Inc., Hoboken, New Jersey.

Slemrod, J. (1992). Did the Tax Reform Act of 1986 Simplify Tax Matters? Journal of Economic Perspectives. 6(1): 45-57.

Steenkamp, Lee-Ann. (2012). Combating Impermissible Tax Avoidance through Efficient Administrative Aproach: what SARS can learn from its Canadian counterpart. the Comparative and International Law Journal of Southern Africa. 45(2): 227-257.

Stiglitz, Joseph E. (1985). The General Theory of Tax Avoidance. National Tax Journal. 38(3): 325-337.

Tsebelis, G. (1989). The Abuse of Probability in Political Analysis: The Robinson Crusoe Fallacy. The American Political Science Review. 83: 77-91.

Tsebelis, G. (1990). Penalty Has No Impact on Crime? A Game Theoretical Analysis. Rationality and Society. 2: 225-286.

Tsebelis, G. (1993). Penalty and Crime: Further Theoretical

Consideration and Empirical Evidence. Journal of Theoretical Politics. 5: 349-374. 